\title{
A Mosaic of Vigna hosei (Craib) Back, a Common Weed in Puerto Rico'
}

\section{J. Enrique Perez and Julio Bird ${ }^{2}$}

\section{INTRODUCTION}

Vigna hosei (Craib) Back is a persistent weed frequently found on roadsides and banks in Puerto Rico. It usually is affected by a mosaic virus which induces mottling, blistering and deformation of the foliage (fig. 1). The present study is part of a major effort directed to identify and characterize the virus diseases of legumes in Puerto Rico.

\section{MATERIALS AND METHODS}

Leaves with mosaic symptoms were collected from the grounds of the Agricultural Experiment Station at Río Piedras. Inoculation and inactivation, dilution endpoint and stability in the frozen state tests were performed as described previously. ${ }^{4}$ Several bean varieties and selections were separately inoculated with the Vigna repens and $V$. hosei viruses to compare the symptoms incited by each virus.

\section{HOST RANGE}

\section{Inoculation by Mechanical Means}

The primary leaves or cotyledons of young actively growing plants were dusted with carborundum 600 grit and then inoculated using a swab moistened with sap expressed from diseased $V$. hosei leaves. A total of 74 species, varieties or selections were inoculated by this mechanical means.

Inoculation via Aphis craccivora

Aphis craccivora Koch normally found feeding and breeding on diseased as well as healthy $V$. hosei plants was presumed to be the insect vector. Virus-free stock cultures of the insect vector were secured by increasing aphids from presumably virus-free $V$. hosei plants on caged healthy seedlings of both $V$. hosei and $V$. repens. Aviruliferous insects were charged with

1 Manuscript submitted by Editorial Board June 1, 1972.

2 Bacteriologist and Director, Department of Plant Pathology and Botany, respectively, Agricultural Experiment Station, Mayagüez Campus, University of Puerto Rico, Río Piedras, P. R.

s Backer, A. C., Flora of Java, Wolters-Noordhoff, N. V., Groningen, Netherlands, p. 642, 1863.

- Pérez, J. E., and Bird, J., A mosaic of Vigna repens in Puerto Rico, J. Agr. Univ. P. R. 55 (4): 468-73, 1971 . 

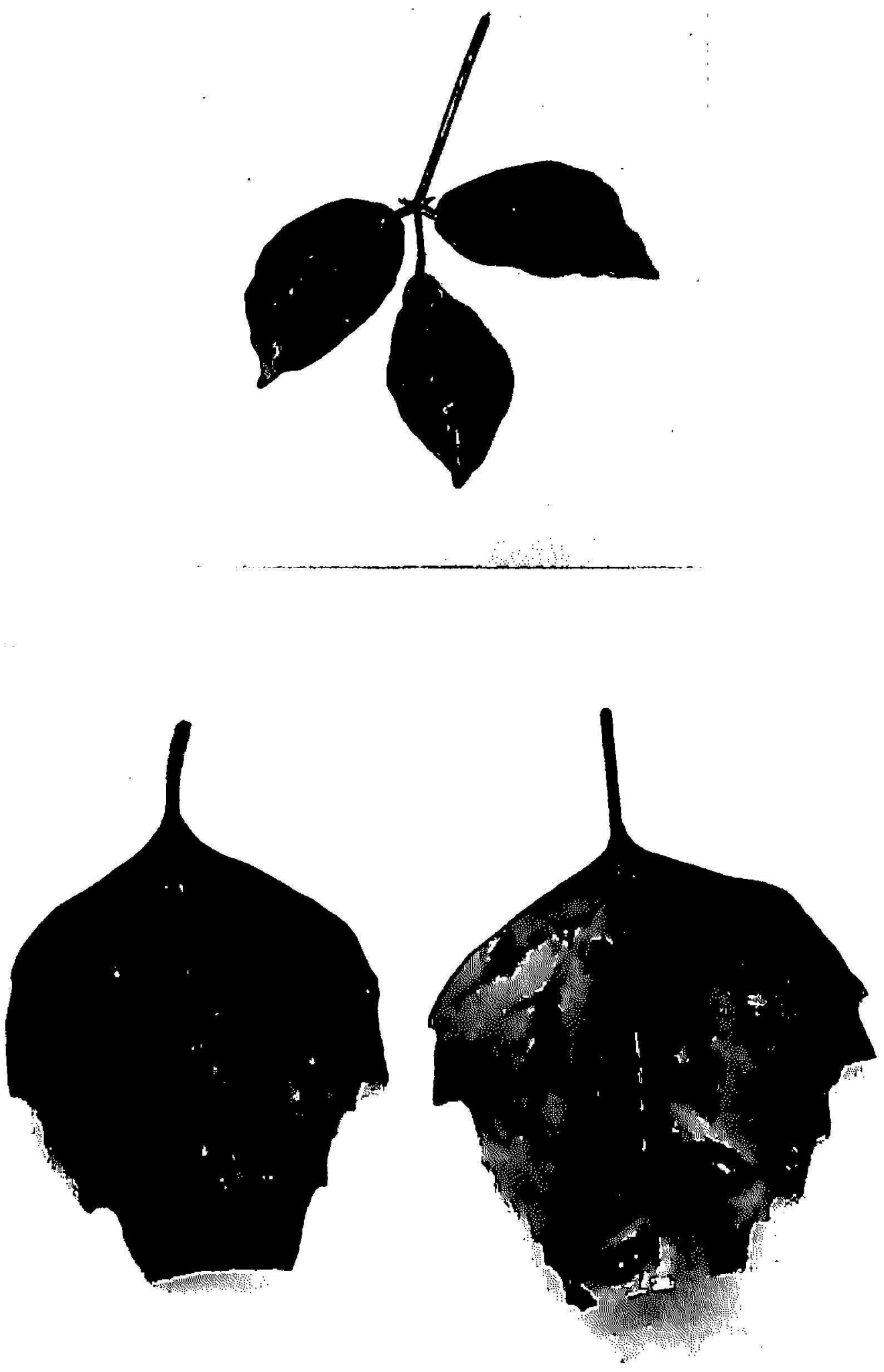

Fıa. 1.-Trifoliate leaf from a mosaic diseased Vigna hosei plant.

FIG. 2.-Lesions incited on Chenopodium amaranticolor by the Vigna hosei virus. 
the virus in the following manner: Apterous forms from aviruliferous stock cultures were removed with the aid of a No. 2 camel hair brush, transferred to plastic laboratory dishes and fasted for a period of 10 to 15 minutes. After this period they were placed on the lower surface of detached, young, mosaic-affected leaves of $V$. hose $i$ and left there for another 10 to 15 minutes. During this period the leaves were observed through a binocular microscope (20X magnification) to determine if the aphids were feeding and probing. For inoculation, test plants were colonized with 10 to 20 insects. The aphids were released on the three youngest leaves and allowed to remain on them for about 1 hour after which time they were killed by spraying with a 0.1percent nicotine sulfate solution. In all cases an equal number of non-inoculated plants were included as controls. Aphids from the various stock colonies were identified as $A$. craccivora by Drs. Silverio Medina-Gaud, Agricultural Experiment Station, University of Puerto Rico, Río Piedras, P.R. and Clyde F. Smith, North Carolina State University, Raleigh, N.C. Plants inoculated via A craccivora were: V. hosei; Cassia occidentalis; Canavalia ensiforme; Phaseolus lathyroides; $P$. vulgaris vars. Marca Diablo, Black Valentine and Blanca * $3 ; P$. lunatus var. Haba de tocón, bean selection 71-2B-R75BK; and Nicotiana glutinosa.

\section{PHYSICAL PROPERTIES}

Physical properties were determined as previously described. ${ }^{5}$

\section{ATTEMPTS TO PURIFY THE VIRUS}

Attempts were made to concentrate and at least partially purify the virus. Systemically infected $C$. occidentalis plants were used. The leaves were collected 2 to 3 weeks after inoculation and chilled. They were then subjected to homogenization in cold $0.1 \mathrm{M} \mathrm{PO}_{4}$ buffer containing citric acid and 2-percent mercaptoethanol and subjected to several alternate periods of high and low speed centrifugation. Another attempt was made using polyethylene glycol 6000.6

\section{RESULTS}

HOST RANGE

\section{Transmission by Mechanical Means}

Susceptible Plants.-Chenopodiaceae: Chenopodium amaranticolor-all inoculated plants developed local chlorotic lesions about $2 \mathrm{~mm}$. in diameter which later became necrotic in the center. Twenty-one days after inocula-

5 Ibid.

6 Hebert, T. T., Precipitation of plant viruses by polyethylene glycol, Phytopathology 53 (3): 362, 1963. 
tion the lesions were red in color (fig. 2). Chenopodium quinoa-chlorotic local lesions similar to those found on $C$. amaranticolor, but larger $(3 \mathrm{~mm}$.). These lesions did not acquire a red hue as in the case of $C$. amaranticolor. Leguminosae: (Numerator denotes number of infected plants while denominator indicates the total number of inoculated plants.) Phaseolus vulgaris var. Black Valentine 16/22, developed reddish vein necrosis and yellowing (fig. 3 ). In other inoculations, beside the reaction on the primary

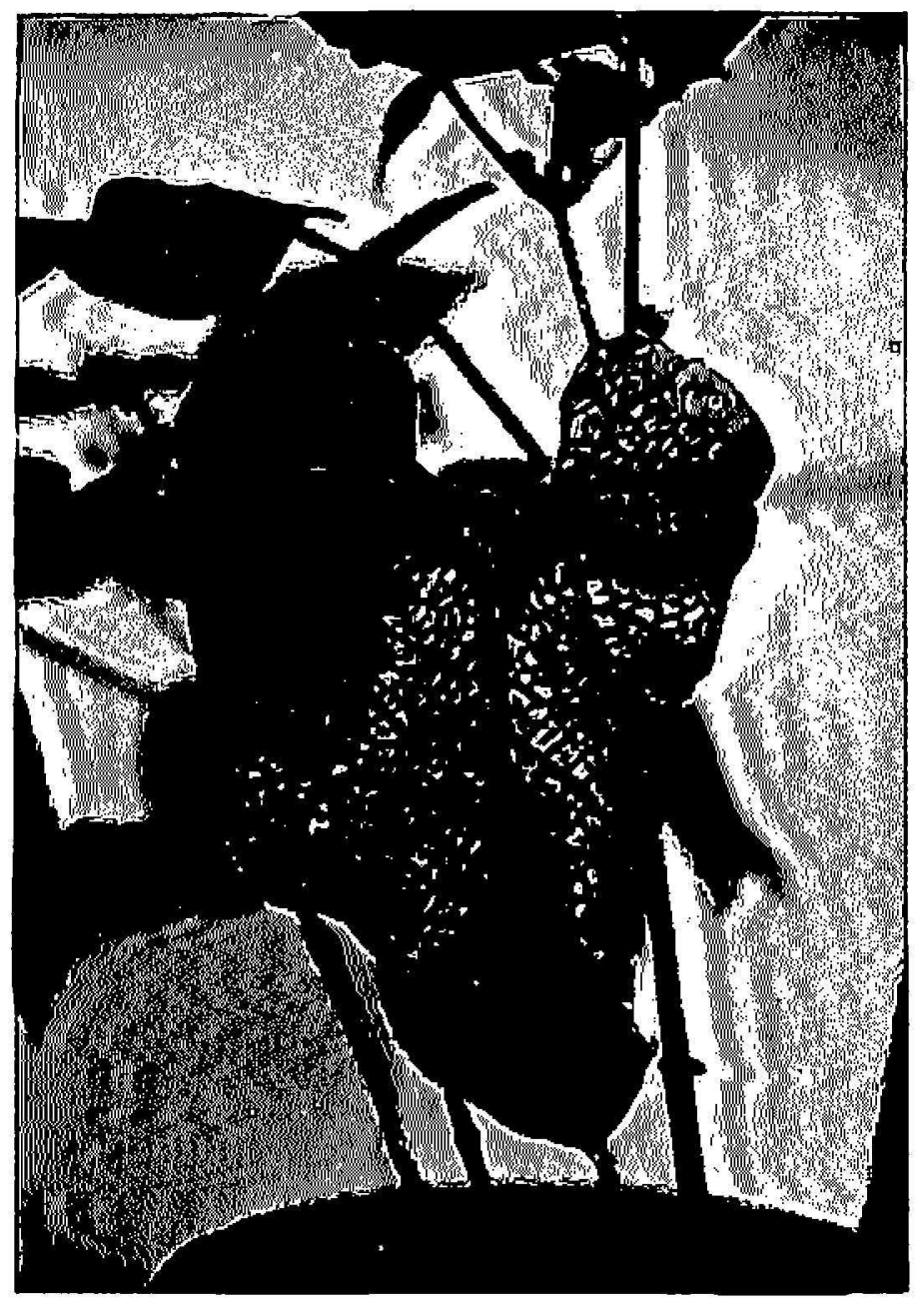

Fıg. 3.-Primary leaf of bean var. Black Valentine showing necrotic veins on a yellow background.

leaves 2/9 developed yellow mosaic of the first trifoliates. Abscission of affected primary leaves was common.

Selections: Blanca $* 1-5 / 19$ developed localized vein necrosis. Affected leaves became chlorotic later. Blanca $* 2-1 / 6$ developed necrotic dots on first trifoliates 13 days after inoculation. This was followed by systemic necrosis. The second trifoliates of the plant became necrotic. Blanca $\# 3-$ $3 / 15$ plants developed chlorosis of primary leaves followed by necrosis of the veinal system and eventually of the stem. Blanca $* 4-4 / 15$, reddish vein 
necrosis of primary leaves was evident. Blanca $* 5-4 / 15$, one plant developed stem necrosis and three developed vein necrosis. Blanca $\# 6-1 / 18$ developed necrotic veinlets on yellow patches at the border of the primary leaves, the third trifoliates also showed vein necrosis (fig. 4). Blanca *7$2 / 7$ plants developed vein necrosis 7 days after inoculation. Two plants developed systemic necrosis. Bonita $-3 / 15$ became epinastic 7 days after inoculation. After 9 days there was crinkling and downward cupping of trifoliates. Three plants died. Rayada-3/14 plants had developed necrosis of the primary leaves 23 days after inoculation. This variety was considered hypersensitive. Pompadour-3/13 plants had developed systemic necrosis

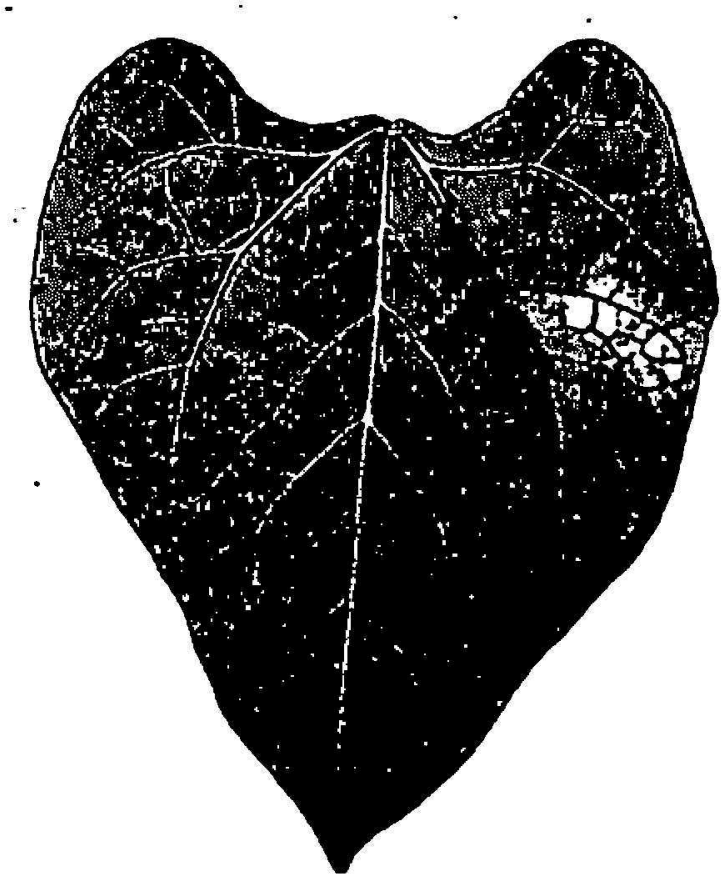

FIG. 4.-Necrotic veins on a yellow patch near the margin of a primary leaf of Phaseolus vulgaris, Selection Blanca \#6.

13 days after inoculation, this was preceded by yellowing of the primary leaves.

Bean introductions: Phaseolus vulgaris, Selection 71-2B-RABK-5/14 had developed yellowing and net necrosis 7 days after inoculation. 71-2BR25BK-4/17 plants had developed small and large net necrosis patches on the primary leaves 7 days after inoculation. 71-2B-R30-BK-6/15 vein necrosis 7 to 13 days after inoculation. All primary leaves had wilted after 17 days. 71-2B-R31-BK-4/15 plants developed chlorosis followed by patches of vein necrosis 13 days after inoculation. 71-2B-R34-BK-5/14 showed yellow chlorotic patches and vein necrosis on primary leaves 15 days after inoculation. $71-2 \mathrm{~B}-\mathrm{R} 46 \mathrm{BK}-1 / 6$ plants showed the characteristic yellowing and necrosis. 71-2B-R75BK-2/6 showed chlorosis and a necrotic patch on primary leaves 7 to 15 days after inoculation. 71-2B- 
R93BI-3/14 same pattern as above in 13 days, but 18 days after inoculation four of the smaller plants had succumbed. 71-2B-R102BK14/14 plants inoculated developed symptoms of common bean mosiac (CBM), and vein netting in patches as described before was. observed on all plants. Thus CBM does not confer, secmingly, protection against the $V$. hosei virus.

Cassia occidentalis-10/14 grcen mosaic with inward cupping of leaflets was observed 10 days after inoculation. Eventually the newer leaves developed oak leaf-pattern mosaic. Phaseolus lathyroides-2/8 plants developed green mosaic and wrinkling 14 to 22 days after inoculation.

Soybean, Glycine max Merr. var. Biloxi-4/12 plants developed yellow patches with necrotic spots in the primary leaves; var. NTU Kaoshwingsame reaction as Biloxi in 5/14 plants inoculated.

Vigna hosei, the natural host of the virus, was difficult to infect by mechanical means. Only $5 / 75$ mechanically inoculated plants developed symptoms.

Reaction of several bean varieties and selections separately inoculated with the mosaic virus of $V$. repens ${ }^{7}$ and the $V$. hosei mosaic virus, for comparative purposes, appear below. All reactions were recorded 7 days after inoculation.

Host

Phaseolus vulgaris (selections)

71-2B-R34-BK

71-2B-R65-BK

71-2B-R75-BK

71-2B-R93-BK

Var. Black Valentine

Soja bean var. NTU

Kaoshwing \#5
Reaction to virus of-

Vigna repens

Vigna hosei

$2 / 7$ vein necrosis over small area of primary leaf, 16 days net necrosis

$2 / 9$ necrotic dots

$1 / 9$ vein necrosis in small patches

$1 / 3$ vein necrosis in patches spots, 16 days net necrosis

6/11 epinasty of primary leaves, yellowing, inward curling of 2nd trifoliates

$7 / 14$ net necrosis and yellowing

4/11 net necrosis progressing towards a complete necrotic patch

$5 / 5$ numerous necrotic veins in patches
Vein necrosis in patches

4/11 vein necrosis in patches

$5 / 8$ vein necrosis in small patches

$3 / 6$ vein necrosis in patches

Insusceptible Plants.-Amaranthaceae: Gomphrena globosa (0/8);

7 Pérez, J. E. and Bird, J., op. cit., p. 468-73. 
Chenopodiaceac: Chenopodium album (0/8); C. capilatum (0/8); Compositae: Lactuca sativa L. var. Great Lakes (0/8); Cruciferae: Cabbage, Brassica oleraceae L. var. Golden Acre (0/8); Cucurbitaceae: Cucumber, Cucumis sativus L. var. Black Diamond (0/34); melon, C. melo L. var. Honey Dew (0/32); pumpkin, Cucurbila pepo var. Small Sugar (0/34). Leguminosae: Phaseolus vulgaris L. Selection 71-2B-R17BK (0/15); 71-2B-R33BK $(0 / 11)$; 71-2B-R66BK (0/14); vars. Borinquen (0/16) and Galana $(0 / 19)$. Phaseolus lunatus var. Henderson Bush (0/17); Vigna P.I.124609 (0/12); Vigna P.I.170859 (0/15); Vigna sesquipedalis (0/14); V. sinensis Endl. var. Black (0/28), cv. Blackeye (0/7), var. Clay $(0 / 8) ;$ V. repens $(0 / 22) ;$ Cassia tora $(0 / 8)$; Cassia obtusifolia (0/8); Canavalia gladiata (0/6); Canavalia ensiforme $(0 / 6)$; Crotalaria striata $(0 / 6)$; Crotalaria anagyroides $(0 / 8)$; Sesbania exaltala (0/8); soybean, Glycine max Merr. vars. Wakashima $(0 / 8)$, Hardee $(0 / 6)$, Palmetto $(0 / 10)$, CNS $/(0 / 8)$, Kanrich $(0 / 15)$; pigeon pea, Cajanus cajan selections $8025(0 / 11), 8027(0 / 20), 8028(0 / 14), 8031$ $(0 / 14), 8033(0 / 20), 8034(0 / 20), 8035(0 / 11), 8036(0 / 13), 8037(0 / 16)$, $8038(0 / 19), 8045(0 / 20), 8046(0 / 16)$. Solanaceae: Tobacco, Nicotiana tabacum L. (NN type) (0/8); N. glutinosa L. (0/8); Datura metel L. (0/16); Jimson weed, Datura stramonium (0/10); pepper Capsicum frutescens var. Blanco del País (0/8).

\section{Transmission via Aphis craccivora}

The virus from $V$. hose $i$ was transmitted via Aphis craccivora to test plants of the following species and varieties: $V$. hosei, $P$. vulgaris vars. Black Valentine, Blanca $* 3$, and also to selection 71-2B-R75BK. In all three cases, the symptoms observed were exactly like those obtained by mechanical inoculation, i.e., vein necrosis superimposed on a chlorotic patch in the primary sites of inoculation. Aphis craccivora was also shown to be capable of transmitting the virus from $V$. hose $i$ to $C$. occidentalis inducing an oak leaf-pattern mosaic on this plant species. V. repens developed mosaic symptoms 12 days after inoculation via the same aphid species. This mosaic was very similar in appearance to the one previously described on $V$. repens. ${ }^{8}$ The virus was also transmitted by the same vector to $P$. lathyroides, $P$. lunatus var. Haba de tocón, and $C$. ensiforme. In a limited number of trials, the virus could not be transmitted to $P$. vulgaris var. Marca Diablo nor to $N$. glutinosa.

\section{PHYSICAL PROPERTIES}

Inoculation with sap from diseased $V$. hosei induced the formation of local lesions on $C$. amaranticolor (fig. 2) up to a dilution of $1 / 10,000$. The

8 Pérez, J. E. and Bird, J., op. cit., p. 468-73. 
virus withstood temperatures of $50^{\circ}$ to $55^{\circ} \mathrm{C}$. but not higher than this when tested for thermal inactivation. It withstood freezing for 24 but not for 35 days.

\section{ATTEMPTS TO PURIFY THE VIRUS}

All efforts made to purify the virus were unsuccessful. The preparations yielded small uninfective pellets containing a considerable amount of green material.

\section{DISCUSSION}

The $V$. hosei mosaic virus has characteristics similar to those of the mosaic of $V$. repens although there are some differences in their physical properties and host range. In the first place the virus from $V$. repens as well as that from $V$. hose $i$ produced similar local lesions in both $C$. amaranticolor and $C$. quinoa. However, the lesions induced by the $V$. hosei mosaic sometimes appear as ringspot-like on C. amaranticolor while those of the $V$. repens mosaic always appear as entire spots. As scen on page 61 the reactions induced by both viruses in various bean selections and varieties are quite similar. Again, the virus from $V$. hosei induced an oak leaf pattern-mosaic on $C$. occidentalis while this host was found insusceptible to the $V$. repens virus. The $V$. repens mosaic virus has a dilution endpoint of $1 / 1,000$ is inactivated between $55^{\circ}$ and $60^{\circ} \mathrm{C}$. and maintains its viability in the frozen state for at least 117 days. On the other hand, the mosaic virus of $V$. hose $i$ infects $P$. lathyroides and $C$. occidentalis systemically both by mechanical means and aphid inoculation. This virus has a dilution endpoint of $1 / 10,000$, is inactivated between $50^{\circ}$ and $55^{\circ} \mathrm{C}$. and withstands freezing for only 24 days.

It is interesting to note that the $V$. hose $i$ virus induced similar symptoms on $C$. occidentalis and the various bean varieties and selections inoculated.

In conclusion it may be stated that the mosaic viruses found on both $V$. hose $i$ and $V$. repens are similar but cannot be considered as one and the same virus. Both viruses are transmitted with difficulty by mechanical means to their natural hosts.

\section{SUMMARY}

A mosaic virus of Vigna hosei (Craib) Back is described. The virus was transmitted by mechanical means to several varieties or selections of Phaseolus vulgaris and to Cassia occidenlalis and $P$. lathyroides. It was transmitted to seven different plant species by means of Aphis craccivora. It resembled somewhat the mosaic virus of $V$. repens on the basis of symptoms produced on several bean varieties and selections. 
64 JOURNAL OF AGRICULTURE OF UNIVERSITY OF PUERTO RICO

\section{RESUMEN}

Se describe un mosaico de Vigna hosei (Craib) Back. Se demostró que el virus puede transmitirse por inoculación mecánica a algunas variedades y selecciones de Phaseolus vulgaris y a Cassia occidentalis y $P$. lathyroides. El virus fue trasmitido a siete especies diferentes de plantas por medio del áfido A phis craccivora. Los sintomas provocados en algunas selecciones y variedades de $P$. mularis por el agente que causa el mosaico de $V$. repens son parecidos. 